\title{
MENINGKATKAN KEMAMPUAN MENYELESAIKAN SOAL CERITA MATEMATIKA SISWA KELAS V UPT. SD NEGERI 16 SARUASO MELALUI MODEL PEMBELAJARAN CREATIVE PROBLEM SOLVING
}

\author{
YURNAILIS \\ yurnailis16@gmail.com
}

\begin{abstract}
This study aims to improve the students' ability to solve math story problems in class V UPT. SD Negeri 16 Saruaso through the Creative Problem Solving learning model. This type of research is Classroom Action Research. The research subjects were students of class V UPT. SD Negeri 16 Saruaso, totaling 18 students, consists of 10 male students and 8 female students. The object of research is the ability to solve math story problems. Research data obtained from observation and learning outcomes tests. The data obtained were analyzed by descriptive quantitative and descriptive qualitative. The criteria for the success of the study were marked by the acquisition of a class average score of $\geq 75$ and a minimum of $75 \%$ of the total number of students reaching KKM (75). The results showed that the use of the Creative Problem Solving learning model could improve the students' ability to solve math story problems in class V UPT. SD Negeri 16 Saruaso. The increase in the ability to solve math story problems is shown by the test results. In the pre-action there were $44.44 \%$ (8 students) of the total 18 students who reached the KKM. The test results in cycle 1 showed that there were $72.22 \%$ (13 students) of the total students who reached the KKM, while in cycle 2 there were $88.89 \%$ (16 students) of the total students who reached the KKM. The average value before cycle was 63.33, while at the end of cycle 1 the average value of the test was 74.44, and at the end of cycle 2 it was 80.
\end{abstract}

Keywords: ability to solve math problem problems, creative problem solving

\begin{abstract}
Abstrak: Penelitian ini bertujuan untuk meningkatkan kemampuan menyelesaikan soal cerita matematika siswa kelas V UPT. SD Negeri 16 Saruaso melalui model pembelajaran Creative Problem Solving. Jenis penelitian ini adalah Penelitian Tindakan Kelas. Subjek penelitian adalah siswa kelas V UPT. SD Negeri 16 Saruaso yang berjumlah 18 siswa, terdiri dari 10 siswa putra dan 8 siswa putri. Objek penelitian adalah kemampuan menyelesaikan soal cerita matematika. Data hasil penelitian diperoleh dari observasi dan tes hasil belajar. Data yang diperoleh dianalisis secara deskriptif kuantitatif dan deskriptif kualitatif. Adapun kriteria keberhasilan penelitian tersebut ditandai dengan perolehan nilai rata-rata kelas $\geq 75$ dan minimal 75\% dari jumlah siswa mencapai KKM (75). Hasil penelitian menunjukkan bahwa penggunaan model pembelajaran Creative Problem Solving dapat meningkatkan kemampuan menyelesaikan soal cerita matematika siswa kelas V UPT. SD Negeri 16 Saruaso. Peningkatan kemampuan menyelesaikan soal cerita matematika ditunjukkan oleh hasil tes. Pada pra tindakan terdapat 44,44\% (8 siswa) dari jumlah 18 siswa yang mencapai KKM. Hasil tes pada siklus 1 menunjukkan ada 72,22\% (13 siswa) dari jumlah siswa yang mencapai KKM, sedangkan pada siklus 2 terdapat $88,89 \%$ (16 siswa) dari jumlah siswa yang mencapai KKM. Nilai rata-rata sebelum siklus sebesar 63,33, sedangkan pada akhir siklus 1 nilai rata-rata tes sebesar 74,44, dan pada akhir siklus 2 sebesar 80 .
\end{abstract}


Kata kunci: kemampuan menyelesaikan soal cerita matematika, creative problem solving

\section{A. Pendahuluan}

Kegiatan belajar mengajar mengandung arti interaksi dari berbagai komponen seperti guru, murid, sarana dan bahan ajar lainnya yang digunakan pada saat kegiatan berlangsung. Lubis (2004: 8) menyatakan bahwa kegiatan Belajar Mengajar (KBM) merupakan kegiatan interaksi antara guru dan murid, antara siswa dengan siswa dan antara siswa dengan sumber belajar lainnya dalam satu kesatuan waktu dalam mencapai tujuan pembelajaran yang telah ditetapkan. Saat ini interaksi antara guru dan murid sangat kurang. Akibatnya akan memberikan pengaruh yang tidak kondusif kepada siswa dalam proses pembelajarannya, seperti siswa menjadi tidak tertantang untuk belajar, tidak fokus pada pelajaran terkait atau bahkan terkesan mengganggu jalannya proses pembelajaran. Dalam meningkatkan mutu pendidikan diperlukan perubahan pola pikir yang akan dijadikan landasan pelaksanaan pendidikan di masa yang akan datang. Peningkatan mutu pendidikan direalisasikan melalui proses pembelajaran. Pada waktu sekarang ini masih ada proses pembelajaran yang hanya terfokus pada guru, dan kurang terfokus pada siswa. Akibatnya kegiatan belajar mengajar lebih menekankan pada pengajaran bukan pada pembelajaran. Kegiatan pengajaran lebih berpihak pada kepentingan orang yang mengajar (guru), sedang kegiatan pembelajaran lebih berpihak pada orang yang belajar (siswa). Agar proses pembelajaran yang terjadi dapat berlangsung efektif maka seorang guru harus dapat mengemban tugasnya dengan baik sebagai pendidik.

Kegiatan pembelajaran tidak hanya menerima informasi dari guru, tetapi mengolah informasi sebagai masukan dalam meningkatkan kemampuan. Namun, guru selama ini mengajarkan matematika dengan hanya menggunakan metode ceramah saja dan belum menggunakan metode mangajar yang bervariasi sehingga siswa kurang dapat memahami pembelajaran matematika dengan baik. Pada pembelajaran matematika tentunya siswa tidak hanya diajarkan dengan ceramah saja, melainkan siswa bisa memahami materi dengan baik yaitu dengan cara pengalaman langsung dan dapat menemukan sendiri pemecahan masalah yang ada dengan pengetahuan dan pengalaman dalam kehidupan sehari-hari siswa. Katagiri (Marsigit, 2009: 3) mengatakan bahwa berpikir matematika meliputi 3 aspek yaitu, sikap matematika, metode memikirkan matematika dan konten matematika. Sikap matematika adalah sikap yang ditunjukkan dengan adanya rasa senang untuk mempelajari matematika, sikap yang mendukung untuk mempelajari matematika, pengetahuan yang cukup untuk mempelajari matematika, rasa ingin tahu, kemauan untuk bertanya, dan kemauan untuk memperoleh keterampilan dan pengalaman matematika. Namun, pada kenyataannya siswa menganggap bahwa matematika sulit untuk dipelajari. Tentu saja hal ini akan mempengaruhi prestasi belajar matematika menjadi rendah. Kenyataan seperti ini sangat memprihatinkan mengingat matematika sangat berpengaruh untuk memecahkan masalah di kehidupan sehari-hari. Pitadjeng (2006: 1) menyatakan bahwa banyak orang tidak menyukai matematika termasuk siswa-siswa yang masih duduk di bangku SD/MI.

Kemampuan menyelesaikan soal cerita matematika juga merupakan salah satu kemampuan matematik yang juga harus dimiliki seorang siswa. Kemampuan menyelesaikan soal cerita dapat memberikan manfaat bagi siswa yaitu siswa mengetahui apa kegunaan dari pokok bahasan yang telah dipelajari. Selain itu, kemampuan siswa dalam mengambil suatu keputusan merupakan manfaat lain yang 
dapat diperoleh dari kemampuan menyelesaikan soal cerita. Berdasarkan data yang didapatkan dari siswa kelas V UPT. SD Negeri 16 Saruaso, sebanyak 7 siswa dari 18 siswa yang mampu menyelesaikan soal cerita matematika dengan baik. Itu berarti kemampuan menyelesaikan soal cerita matematika siswa kelas V UPT. SD Negeri 16 Saruaso masih rendah. Kesulitan dalam menyelesaikan soal cerita merupakan suatu masalah yang perlu ditangani pemecahannya. Dengan masalah ini dikhawatirkan akan mengakibatkan siswa kurang memahami permasalahan-permasalahan dalam kehidupan sehari-hari yang berhubungan dengan matematika. Berbagai permasalahan di atas memerlukan solusi dan penanganan yang tepat agar pembelajaran dapat berlangsung dengan baik. Salah satu langkah yang diambil adalah menggunakan model pembelajaran creative problem solving. Model pembelajaran berbasis Creative Problem Solving merupakan model pembelajaran yang memusatkan pada pengajaran dan keterampilan pemecahan masalah yang diikuti dengan penguatan keterampilan. Ketika dihadapkan dengan suatu masalah, siswa dapat melakukan keterampilan memecahkan masalah untuk memilih dan mengembangkan tanggapannya. Mengingat kemampuan menyelesaikan soal cerita matematika siswa kelas V UPT. SD Negeri 16 Saruaso rendah, maka peneliti bermaksud menggunakan model pembelajaran Creative Problem Solving (CPS) untuk meningkatkan kemampuan menyelesaikan soal cerita siswa kelas V UPT. SD Negeri 16 Saruaso.

\section{B. Metodologi Penelitian}

Jenis penelitian yang digunakan dalam penelitian ini adalah penelitian tindakan kelas. Menurut Suhardjono (2006: 68), penelitian tindakan kelas adalah penelitian yang dilakukan di kelas dengan tujuan memperbaiki atau meningkatkan mutu praktik pembelajaran. Menurut Hamzah B.Uno (2013: 41), penelitian tindakan kelas merupakan penelitian yang dilakukan oleh seorang guru di dalam kelasnya sendiri melalui refleksi diri, dengan tujuan untuk memperbaiki kinerjanya sebagai guru, sehingga hasil belajar siswa menjadi meningkat. Dengan demikian penelitian tindakan kelas adalah penelitian yang dilakukan guru untuk memperbaiki dan meningkatkan mutu pembelajaran di kelas, sehingga hasil belajar siswa dapat meningkat. Hamzah B. Uno (2011: 62) menyatakan bahwa penelitian partisipatif merupakan penelitian tindakan yang dilakukan sendiri oleh peneliti dan diamati bersama dengan rekan sejawat. Sedangkan penelitian kolaboratif adalah penelitian yang melibatkan rekan sejawat sebagai bagian dari suatu penelitian. Dalam penelitian ini seorang kolaboratif atau dapat disebut kolaborator, kolaborator bertugas untuk mengamati jalannya tindakan penelitian. Penelitian ini merupakan penelitian kolaboratif. Subjek penelitian ini adalah siswa kelas V UPT. SD Negeri 16 Saruaso Kecamatan Tanjung Emas Kabupaten Tanah Datar sebanyak siswa 18 anak dengan pertimbangan bahwa kemampuan menyelesaikan soal cerita matematika rendah dan guru kelas V UPT. SD Negeri 16 Saruaso Kecamatan Tanjung Emas Kabupaten Tanah Datar. Objek Penelitian ini ialah kemampuan siswa dalam menyelesaikan soal cerita matematika. Penelitian ini dilaksanakan di kelas V UPT. SD Negeri 16 Saruaso Kecamatan Tanjung Emas Kabupaten Tanah Datar. Siswa kelas V tersebut berjumlah 18 siswa, terdiri dari 10 siswa putra dan 8 siswa putri. Keadaan ruang kelas $\mathrm{V}$ cukup rapi dan bersih, di dinding kelas sebelah belakang dipasang beberapa macam hasil karya siswa. Meja dan kursi siswa masih di tata secara konvensional dengan rapi sehingga cukup nyaman untuk melaksanakan proses belajar mengajar, tetapi kurang efektif apabila dalam proses belajar mengajar menggunakan metode diskusi. 


\section{Hasil dan Pembahasan}

\section{Data sebelum tindakan atau (Prasiklus)}

Kegiatan prasiklus dilaksanakan pada hari Kamis tanggal 30 Januari 2020. Kegiatan prasiklus dilakukan dengan mengambil data tentang kondisi awal siswa. Penelitian berlangsung dalam dua siklus dan direncanakan dengan merancang penelitian, dan peneliti berkolaborasi dengan guru kelas. Peneliti berperan sebagai observer, sementara guru kelas tetap berperan sebagai pelaksana tindakan atau pelaksana pembelajaran. Pada saat peneliti melakukan observasi peneliti melihat bahwa penyampaian pembelajaran matematika di UPT. SD Negeri 16 Saruaso, guru belum menggunakan model pembelajaran Creative Problem Solving. Selain itu, guru juga melakukan pembelajaran secara konvensional, hanya menggunakan metode tertentu yang bersifat monoton pada materi soal cerita matematika. Oleh karenanya dalam hal ini siswa tidak terlalu antusias dan merasa jenuh atau bosan dalam mengikuti pembelajaran matematika khususnya pada materi soal cerita matematika. Kurangnya keantusiasan siswa dalam pembelajaran matematika ini mengakibatkan nilai siswa dalam materi soal cerita matematika menjadi rendah.

Tabel Hasil Belajar Peserta Didik Pra Siklus

\begin{tabular}{|c|c|c|c|c|c|}
\hline \multirow[b]{2}{*}{ No } & \multirow{2}{*}{ Nama Peserta Didik } & \multirow[b]{2}{*}{$\mathrm{KKM}$} & \multirow[b]{2}{*}{ Nilai } & \multicolumn{2}{|c|}{ Keterangan } \\
\hline & & & & Tuntas & Belum Tuntas \\
\hline 1 & Alfaidit Glensky & 75 & 60 & & $\sqrt{ }$ \\
\hline 2 & Alysha Maharani & 75 & 80 & $\sqrt{ }$ & \\
\hline 3 & Asysyfa Livi Mayaddah & 75 & 40 & & $\sqrt{ }$ \\
\hline 4 & Chintia Agusti melani & 75 & 80 & $\sqrt{ }$ & \\
\hline 5 & Dela Syafitri & 75 & 60 & & $\sqrt{ }$ \\
\hline 6 & Fajar Ahmad & 75 & 80 & $\sqrt{ }$ & \\
\hline 7 & Ghilang Buana & 75 & 60 & & $\sqrt{ }$ \\
\hline 8 & Giyo Fernando Saputra & 75 & 40 & & $\sqrt{ }$ \\
\hline 9 & Hanifil Ikram & 75 & 20 & & $\sqrt{ }$ \\
\hline 10 & Indah Pratiwi & 75 & 80 & $\sqrt{ }$ & \\
\hline 11 & Irfan Mustafa & 75 & 60 & & $\sqrt{ }$ \\
\hline 12 & Liza Mardia & 75 & 80 & $\sqrt{ }$ & \\
\hline 13 & Mayliza Afriani & 75 & 100 & $\sqrt{ }$ & \\
\hline 14 & Muhammad Farhan & 75 & 60 & & $\sqrt{ }$ \\
\hline 15 & $\begin{array}{l}\text { M u h a m m a d K e vi } n \\
\text { Marfiansyah }\end{array}$ & 75 & 80 & $\sqrt{ }$ & \\
\hline 16 & Muhammad Rafli Saputra & 75 & 40 & & $\sqrt{ }$ \\
\hline 17 & Muhammad Reno Dani & 75 & 80 & $\sqrt{ }$ & \\
\hline 18 & Ningsih Rahmah Dani & 75 & 40 & & $\sqrt{ }$ \\
\hline \multicolumn{2}{|c|}{ Jumlah } & & 1140 & 8 & 10 \\
\hline \multicolumn{2}{|c|}{ Nilai rata-rata kelas } & & 63,33 & & \\
\hline \multicolumn{2}{|c|}{ Presentase } & & & $44,44 \%$ & $55.56 \%$ \\
\hline
\end{tabular}

Berdasarkan tabel di atas, diketahui bahwa selisih antara nilai tertinggi dengan nilai nilai terendah adalah 80. Siswa yang memiliki nilai terendah masih jauh dari Kriteria Ketuntasan Minimal (KKM) yaitu sebesar 75. Untuk mencapai Kriteria Ketuntasan Minimal (KKM), sebanyak 10 anak atau sekitar 55,56\% harus ditingkatkan kemampuannya dalam menyelesaikan soal cerita matematika. Selain hal tersebut dapat diketahui juga bahwa siswa yang belum mencapai KKM lebih banyak dari pada siswa yang sudah mencapai KKM. 


\section{Deskripsi Penelitian Siklus I}

Pada akhir tindakan siklus I ini dilakukan evaluasi belajar siswa untuk melihat tingkat pencapaian hasil belajar siswa. Pengukuran hasil belajar siswa dilakukan dengan memberikan soal-soal evaluasi secara individu kepada siswa. Hasil evaluasi siklus I dapat dilihat dalam tabel berikut ini.

\section{Tabel Hasil Belajar Peserta Didik Siklus I}

\begin{tabular}{|c|c|c|c|c|c|}
\hline \multirow[b]{2}{*}{ No } & \multirow{2}{*}{ Nama Peserta Didik } & \multirow[b]{2}{*}{ KKM } & \multirow[b]{2}{*}{ Nilai } & \multicolumn{2}{|c|}{ Keterangan } \\
\hline & & & & Tuntas & Belum Tuntas \\
\hline 1 & Alfaidit Glensky & 75 & 80 & $\sqrt{ }$ & \\
\hline 2 & Alysha Maharani & 75 & 80 & $\sqrt{ }$ & \\
\hline 3 & Asysyfa Livi Mawaddah & 75 & 60 & & $\sqrt{ }$ \\
\hline 4 & Chintia Agusti melani & 75 & 80 & $\sqrt{ }$ & \\
\hline 5 & Dela Syafitri & 75 & 60 & & $\sqrt{ }$ \\
\hline 6 & Fajar Ahmad & 75 & 80 & $\sqrt{ }$ & \\
\hline 7 & Ghilang Buana & 75 & 80 & $\sqrt{ }$ & \\
\hline 8 & Giyo Fernando Saputra & 75 & 80 & $\sqrt{ }$ & \\
\hline 9 & Hanifil Ikram & 75 & 80 & $\sqrt{ }$ & \\
\hline 10 & Indah Pratiwi & 75 & 40 & & $\sqrt{ }$ \\
\hline 11 & Irfan Mustafa & 75 & 80 & $\sqrt{ }$ & \\
\hline 12 & Liza Mardia & 75 & 80 & $\sqrt{ }$ & \\
\hline 13 & Mayliza Afriani & 75 & 100 & $\sqrt{ }$ & \\
\hline 14 & Muhammad Farhan & 75 & 60 & & $\sqrt{ }$ \\
\hline 15 & $\begin{array}{l}\text { M u h a m m a d Kevin } \\
\text { Marfiansyah }\end{array}$ & 75 & 80 & $\sqrt{ }$ & \\
\hline 16 & Muhammad Rafli Saputra & 75 & 60 & & $\sqrt{ }$ \\
\hline 17 & Muhammad Reno Dani & 75 & 80 & $\sqrt{ }$ & \\
\hline 18 & Ningsih Rahmah Dani & 75 & 80 & $\sqrt{ }$ & \\
\hline \multicolumn{2}{|c|}{ Jumlah } & & 1340 & 13 & 5 \\
\hline \multicolumn{2}{|c|}{ Nilai rata-rata kelas } & & 74,44 & & \\
\hline \multicolumn{2}{|c|}{ Presentase } & & & $72,22 \%$ & $27,78 \%$ \\
\hline
\end{tabular}

Berdasarkan data hasil penelitian siklus I yang disajikan dalam tabel di atas, nilai tertinggi siswa 100 dan nilai terendah 40. Dengan nilai rata-rata kelas hanya mencapai 74,44 pada rentang nilai 0-100. Perbandingan nilai prasiklus dengan siklus I dapat dilihat pada tabel berikut ini:

Tabel Perbandingan Nilai Peserta Didik Pra Siklus dan Siklus I

\begin{tabular}{|c|c|c|}
\hline Aspek yang diamati & Nilai Prasiklus & Nilai Siklus I \\
\hline Nilai Tertinggi & 100 & 100 \\
\hline Nilai Terendah & 20 & 40 \\
\hline Nilai Rata-rata & 63,33 & 74,44 \\
\hline Persentase siswa tuntas & $44,44 \%$ & $72,22 \%$ \\
\hline Persentase siswa belum tuntas & $55,56 \%$ & $27,78 \%$ \\
\hline
\end{tabular}

Dari data di atas dapat disimpulkan bahwa, antara nilai siswa pada prasiklus yang belum dikenai tindakan dengan siklus I yang telah dikenai tindakan mengalami kenaikan. Nilai rata-rata kelas pada saat prasiklus 63,33. Sedangkan pada saat siklus I mencapai 74,44. Persentase siswa yang belum tuntas pada prasiklus adalah $72,22 \%$. Sedangkan pada siklus I persentase siswa yang belum tuntas adalah 
27,78\%. Berdasarkan data hasil dari siklus I, nilai rata-rata kelas belum mencapai kriteria penelitian sehingga penelitian dilanjutkan ke siklus II.

Berdasarkan kekurangan-kekurangan pada siklus I, maka diadakan perencanaan perbaikan pembelajaran pada siklus II. Berdasarkan hasil refleksi pada pertemuan pertama, kedua dan ketiga siklus I, maka dapat diambil kesimpulan bahwa kekurangan- kekurangan yang muncul pada siklus I adalah sebagai berikut: 1) Selama proses diskusi kebanyakan siswa masih kesulitan dalam mengungkapkan pendapat, hasil diskusi atau hasil pemikiran mereka. Siswa masih cenderung diam, malu dan takut untuk berbicara. Sebagian besar siswa masih cenderung diam, malu dan takut untuk berbicara. Hal tersebut mungkin terjadi karena siswa belum terbiasa melakukan diskusi; 2) Pada kegiatan diskusi tidak semua anggota kelompok bekerja dengan baik. Hal tersebut dimungkinkan antara anggota kelompok tidak saling cocok ataupun karena belum terbiasa dalam bekerja dalam kelompok; 3) Ada beberapa siswa yang kurang memahami materi yang sedang disampaikan oleh guru. Hal tersebut terjadi karena saat guru menjelaskan materi, perhatian siswa belum terpusat; dan 4) Terdapat beberapa siswa yang bermain sendiri bahkan mengganggu temannya. Hal itu kemungkinan terjadi karena perhatian guru pada beberapa siswa kurang, sehingga siswa tersebut cenderung bermain sendiri dan mengganggu temannya.

\section{Deskripsi Penelitian Siklus II}

Peneliti ingin meminimalisir kekurangan-kekurangan pada siklus I dan memperbaikinya agar mampu mencapai hasil penelitian seperti yang telah ditentukan. Berikut adalah rencana perbaikan yang akan dilaksanakan di siklus selanjutnya yaitu siklus II: 1) Saat diskusi seluruh siswa dimotivasi agar tidak takut dalam menggungkapkan pendapat. Siswa juga diberi pengertian bahwa jika pendapat yang mereka sampaikan kurang tepat tidak masalah, nanti akan diperbaiki oleh teman atau guru; 2) Kegiatan diskusi atau pengerjaan LKS dibuat kompetisi. Apabila terdapat kelompok yang selesai lebih dahulu dan jawaban benar akan diberikan penghargaan; 3) Seluruh siswa diminta untuk memperhatikan penjelasan guru, apabila terdapat siswa yang belum memperhatikan maka penjelasaannya tidak dilanjutkan; dan 4) Pada awal pembelajaran siswa diingatkan untuk tidak menyibukkan diri sendiri atau mengganggu temannya saat pembelajaran, apabila masih dilakukan,siswa akan mendapatkan sanksi yaitu pengurangan nilai. Pada akhir tindakan siklus II ini dilakukan evaluasi belajar siswa untuk melihat tingkat pencapaian hasil belajar siswa. Hasil evaluasi Siklus II dapat dilihat dalam tabel berikut ini.

Tabel Hasil Belajar Peserta Didik Siklus II

\begin{tabular}{|c|c|c|c|c|c|}
\hline \multirow[b]{2}{*}{ No } & \multirow{2}{*}{ Nama Peserta Didik } & \multirow[b]{2}{*}{ KKM } & \multirow[b]{2}{*}{ Nilai } & \multicolumn{2}{|c|}{ Keterangan } \\
\hline & & & & Tuntas & Belum Tuntas \\
\hline 1 & Alfaidit Glensky. & 75 & 80 & $\sqrt{ }$ & \\
\hline 2 & Alysha Maharani & 75 & 80 & $\sqrt{ }$ & \\
\hline 3 & Asysyfa Livi Mawaddah & 75 & 80 & $\sqrt{ }$ & \\
\hline 4 & Chintia Agusti melani & 75 & 80 & & \\
\hline 5 & Dela Syafitri & 75 & 80 & $\sqrt{ }$ & \\
\hline 6 & Fajar Ahmad & 75 & 80 & $\sqrt{ }$ & \\
\hline 7 & Ghilang Buana & 75 & 80 & $\sqrt{ }$ & \\
\hline 8 & Gixo Fernando Saputra & 75 & 100 & $\sqrt{ }$ & \\
\hline 9 & Hanifil Ikram & 75 & 80 & $\sqrt{2}$ & \\
\hline 10 & Indah Pratiwi & 75 & 60 & & $\checkmark$ \\
\hline 11 & Irfan Mustafa & 75 & 80 & $\sqrt{ }$ & \\
\hline 12 & Liza Mardia & 75 & 80 & $\sqrt{ }$ & \\
\hline 13 & Mayliza Afriani & 75 & 100 & $\sqrt{ }$ & \\
\hline 14 & Muhammad Farhan & 75 & 40 & & $\sqrt{ }$ \\
\hline 15 & $\begin{array}{l}\text { Muh a m m a d } K \text { Kevin } \\
\text { Marfiansyah }\end{array}$ & 75 & 80 & $\sqrt{ }$ & \\
\hline 16 & Muhammad Rafli Saputra & 75 & 80 & $\sqrt{ }$ & \\
\hline 17 & Muhammad Reno Dani & 75 & 80 & $\sqrt{ }$ & \\
\hline 18 & Ningsih Rahmah Dani & 75 & 100 & $\sqrt{ }$ & \\
\hline \multicolumn{2}{|c|}{ Jumlah } & & 1140 & 16 & 2 \\
\hline \multirow{2}{*}{\multicolumn{2}{|c|}{$\begin{array}{l}\text { Nilai rata-rata kelas } \\
\text { Presentase }\end{array}$}} & & 80 & & \\
\hline & & & & $88,89 \%$ & $11.11 \%$ \\
\hline
\end{tabular}


Berdasarkan data hasil penelitian siklus II yang disajikan dalam tabel di atas, nilai tertinggi siswa 100 dan nilai terendah 40. Dengan nilai rata-rata kelas hanya mencapai 80 pada rentang nilai $0-100$. Persentase siswa yang tuntas adalah $88,89 \%$ dan persentase siswa yang belum tuntas adalah $11,11 \%$

Perbandingan nilai prasiklus, siklus I dan siklus II dapat dilihat pada tabel berikut ini:

Tabel Perbandingan Nilai Peserta Didik Pra Siklus dan Siklus II

\begin{tabular}{|l|l|l|}
\hline Aspek yang diamati & Nilai Siklus I & \multicolumn{1}{|c|}{ Nilai Siklus II } \\
\hline Nilai Tertinggi & 100 & 100 \\
\hline Nilai Terendah & 40 & 40 \\
\hline Nilai Rata-rata & 74,44 & 80 \\
\hline Persentase siswa tuntas & $72,22 \%$ & $88,89 \%$ \\
\hline Persentase siswa belum tuntas & $27,78 \%$ & $11,11 \%$ \\
\hline
\end{tabular}

Dari data diatas dapat disimpulkan bahwa, antara nilai siswa pada prasiklus yang belum dikenai tindakan dengan siklus I yang telah dikenai tindakan mengalami kenaikan. Nilai rata-rata rata kelas pada saat prasiklus 63,33, sedangkan pada saat siklus I mencapai 74,44. Selain itu juga, dari data di atas disimpulkan bahwa nilai siswa pada siklus II mengalami kenaikan bila dibandingkan dengan nilai siswa pada siklus I. Nilai rata-rata kelas pada siklus I yaitu 74,44, sedangkan nilai rata-rata kelas pada siklus II yaitu 80. Hasil penelitian pada siklus II sudah memenuhi kriteria keberhasilan penelitian yaitu nilai rata-rata kelas minimal 75 pada rentang nilai 0 100.Selain itu, tindakan yang dilakukan dalam proses pembelajarannya sudah terlihat adanya perbaikan.Sehingga tidak dilanjutkan ke siklus berikutnya.

\section{Pembahasan}

Penelitian ini merupakan penelitian tentang penggunaan model pembelajaran Creative Problem Solving untuk meningkatkan kemampuan menyelesaikan soal cerita matematika siswa kelas V UPT. SD Negeri 16 Saruaso. Kemampuan menyelesaikan soal cerita matematika dengan model pembelajaran Creative Problem Solving pada siswa kelas $\mathrm{V}$ mengalami peningkatan yang cukup baik, yaitu pada siklus 1 nilai ratarata siswa mencapai 74,44 dan pada siklus 2 mengalami peningkatan menjadi 80 . Diperolehnya hasil di atas dimungkinkan karena dalam pembelajaran menggunakan model CPS, siswa berperan aktif dalam proses pembelajaran dan secara kreatif berusaha menemukan solusi dari permasalahan yang diajukan, saling berinteraksi dengan teman maupun guru, saling bertukar pikiran, sehingga wawasan dan daya pikir mereka berkembang. Hal ini akan banyak membantu siswa dalam meningkatkan kemampuan pemecahan masalah, sehingga ketika mereka dihadapkan dengan suatu pertanyaan, mereka dapat melakukan keterampilan memecahkan masalah untuk memilih dan mengembangkan tanggapannya tidak hanya dengan cara menghafal tanpa memperdalam dan memperluas pemikirannya.

Kondisi ini didorong oleh suasana pada pembelajaran model CPS yang menuntut siswa untuk selalu aktif selama pembelajaran berlangsung, yaitu aktif untuk menemukan solusi dari masalah secara kreatif, juga aktif berinteraksi dengan siswa lain melalui kegiatan diskusi kelompok maupun diskusi kelas serta presentasi di depan kelas. Selama pembelajaran berlangsung guru bertindak sebagai fasilitator dan motivator, disamping memberikan kemudahan (fasilitas) belajar kepada 
siswa dan siswa berinteraksi dengan sumber-sumber belajar yang dapat mempermudah proses belajarnya. Jadi dalam pembelajaran dengan model CPS, aktivitas siswa mendominasi proses pembelajaran, atau dengan kata lain pembelajaran berpusat pada siswa. Hal ini selaras dengan saran Nasution (1995: 23) bahwa pengajaran modern hendaknya mengutamakan aktivitas siswa. Demikian pula teori belajar Bruner, yang menyatakan bahwa pembelajaran adalah siswa belajar melalui keterlibatan aktif dengan konsep dan prinsip-prinsip dalam memecahkan masalah, dan guru berfungsi sebagai motivator bagi siswa dalam mendapatkan pengalaman yang memungkinkan siswa menemukan dan memecahkan masalah. Hal tersebut relevan dengan penjabaran implikasi teori kognitif Piaget yang antara lain menyatakan bahwa dalam pembelajaran memusatkan perhatian kepada berpikir atau proses mental peserta didik, mengutamakan peran peserta didik dalam berinisiatif sendiri dan keterlibatan aktif dalam kegiatan belajar mengajar (Hidayat, 2005: 7).

Pelaksanaan tindakan pada penelitian ini dilaksanakan dalam 2 siklus dan masing-masing siklus terdiri dari 2 pertemuan. Hasil penelitian menunjukkan bahwa kegiatan pembelajaran sudah berjalan dengan baik dan sesuai dengan indikator kinerja yang telah ditentukan. Pada siklus I, siswa sudah melaksanakan model pembelajaran Creative Problem Solving dengan baik. Hal itu dapat dibuktikan dengan hasil belajar siswa pada siklus I yang mendapatkan nilai rata-rata 74,44 yang termasuk dalam kategori baik, meskipun belum memenuhi kriteria ketuntasan minimal yaitu 75 . Berdasarkan data-data tersebut, peneliti menyimpulkan bahwa pelaksanaan pembelajaran pada siklus I masih belum berhasil. Untuk itu peneliti dan observer melaksanakan tindakan pada siklus berikutnya dengan melakukan refleksi, kekurangan-kekurangan yang muncul pada siklus I akan diperbaiki pada siklus berikutnya yaitu siklus II.

Pada siklus II, hasil belajar siswa dalam pembelajaran dengan model pembelajaran Creative Problem Solving berjalan dengan sangat baik. Hal itu dapat dibuktikan pada siklus II hasil belajar siswa mengalami peningkatan yaitu mencapai 80 yang termasuk dalam kategori sangat baik karena sudah memenuhi kriteria ketuntasan minimal. Berdasarkan data-data tersebut, peneliti menyimpulkan bahwa pelaksanaan pembelajaran pada siklus II sudah dikatakan berhasil. Oleh karena itu peneliti menyudahi pelaksanaan tindakan hanya sampai pada siklus II. Secara keseluruhan peningkatan kemampuan menyelesaikan soal cerita matematika siswa kelas V UPT. SD Negeri 16 Saruaso tahun melalui model pembelajaran Creative Problem Solving telah mencapai titik keberhasilan.

Keberhasilan pembelajaran Matematika siswa kelas V UPT. SD Negeri 16 Saruaso tahun ditandai dengan adanya peningkatan dan perubahan pada setiap siklus, Asrori (2009: 23) menyatakan bahwa pembelajaran merupakan suatu proses perubahan tingkah laku yang diperoleh melalui pengalaman individu yang bersangkutan. Dengan adanya pelaksanaan pembelajaran yang diberikan oleh guru, artinya guru telah memberikan pengalaman belajar langsung kepada setiap siswa. Dalam penelitian ada anak yang masih belum paham tentang menyelesaikan soal cerita matematika, terbukti dengan masih adanya nilai siswa yang belum mencapai KKM, ini disebabkan karena siswa tersebut belum dapat memahami operasi hitung. Hal tersebut mengacu pada pendapat Ausubel (dalam Depdiknas 2006) dalam M. Jaenuri yang mengatakan bahwa pengetahuan dasar yang dimiliki siswa akan sangat menentukan bermakna tidaknya suatu proses pembelajaran. Itulah sebabnya para guru harus mengecek, memperbaiki dan menyempurnakan pengetahuan para siswa sebelum membahas materi baru. 


\section{Penutup}

Berdasarkan hasil penelitian dan pembahasan dapat disimpulkan bahwa model pembelajaran Creative Problem Solving dapat meningkatkan kemampuan menyelesaikan soal cerita matematika siswa kelas V UPT. SD Negeri 16 Saruaso Kecamatan Tanjung Emas Kabupaten Tanah Datar. Peningkatan kemampuan menyelesaikan soal cerita tersebut dapat dilihat dari hasil tes. Pada pretes terdapat 44,44\% (7 siswa) dari jumlah 18 siswa yang mencapai KKM. Hasil tes pada siklus 1 menunjukkan ada 72,22\% (13 siswa) dari jumlah siswa yang mencapai KKM, sedangkan pada siklus 2 terdapat $88,89 \%$ (16 siswa) dari jumlah siswa yang mencapai KKM. Nilai rata-rata sebelum siklus sebesar 63,33, sedangkan pada akhir siklus 1 nilai rata-rata tes sebesar 74,44, dan pada akhir siklus 2 sebesar 80 .

\section{Daftar Pustaka}

Arikunto, Suharsimi. (2007). Dasar-Dasar Evaluasi Pendidikan. reved. Jakarta: Bumi Aksara.

Ashlock. (2003). Guiding Each Child's Learning of Mathematics. Colombus: Bell Company

Bitman dan Clara. (2008). Pemecahan Masalah Matematika. Jakarta: Dirjen Dikti Depdiknas

Hidayat, Komaruddin. 2005. Active Learning. Yogyakarta: Yappendis

Isdiardi. (2004). Strategi Kemampuan Menyelesaikan Soal Cerita. Yogyakarta: FMIPA UNY

Lubis, Hari. S.B. dan Martani Husaini. (2004). Teori Organisasi (Suatu Pendekatan Makro), Pusat Antar Universitas Ilmu-ilmu Sosial Universitas Indonesia, Jakarta.

Mardjuki. (1999). Pembelajaran Soal Cerita dalam Matematika. Laporan

Penelitian. Yogyakarta: FMIPA UNY.

Marsigit. (2009). Pembudayaan Matematika di Sekolah Untuk Mencapai Keunggulan Bangsa.

Mirwan, Agus. (1989). Teori Mengajar. Yogyakarta: Sumbangsih.

Muklis. (1996). Dasar-dasar dan Strategi Pembelajaran. Jakarta: Gramedia.

Muslich. (2008). KTSP Pembelajaran Berbasis Kompetensi dan Kontekstual. Jakarta: Bumi Aksara.

Munandar, Utami. (2002). Kreativitas dan Keberbakatan Strategi Mewujudkan Potensi Kreatif dan Bakat. Jakarta: Gramedia Pustaka Utama.

Munandar, Utami. (2009). Pengembangan Kreativitas Anak Berbakat. Jakarta: Rineka Cipta

Nasution. 1995. Didaktik asas-asas mengajar. Jakarta: Bumi Aksara.

Raharjo, Marsudi. (2009). Modul Matematika SD Program Bermutu Pembelajaran Soal Cerita di SD. Jakarta: Depdiknas Dirjen PMPTK PPPPTK

Saleh, Haji. (1992). Diagnosis Kesulitan Siswa dalam Menyelesaikan Soal Cerita di Kelas V SD Negeri Percobaan Surabaya. Tesis. PPs IKIP Surabaya

Soemartono. (1983). Pedoman Umum Matematika SD. Jakarta: Depdikbud

Suherman, Erman, dkk. (2003). Strategi Pembelajaran Kontemporer. Bandung: UPI

Suhardjono. (2006). Penelitian Tindakan Kelas. Jakarta: Penerbit Bumi Aksara.

Sukarsih, Endang. (1998). Pengaruh Kemampuan Verbal dan Kemampuan Membuat Model Matematika. Jakarta: FMIPA UNY

Suryosubroto. (2009). Proses Belajar Mengajar di Sekolah. Jakarta: Rineka Cipta 
Uno, Hamzah. (2011). Belajar Dengan Pendekatan PAILKEM. Jakarta: Jakarta BumiAksara

Parnes, S. J. (1985). Creative Problem Solving. Association for Supervision and Curriculum Development.

Pitadjeng. (2006). Pembelajaran Matematika yang Menyenangkan. Jakarta : Depdiknas Dirjen Dikti

Wijaya. (2007). Pendidikan Remedial. Bandung: Rosdakarya. 